Review

\title{
How Close We Are to Achieving Commercially Viable Large-Scale Photobiological Hydrogen Production by Cyanobacteria: A Review of the Biological Aspects
}

\section{Hidehiro Sakurai ${ }^{1, *}$, Hajime Masukawa ${ }^{1,2}$, Masaharu Kitashima ${ }^{3}$ and Kazuhito Inoue ${ }^{1,3}$}

1 Research Institute for Photobiological Hydrogen Production, Kanagawa University, Tsuchiya, Hiratsuka, Kanagawa 259-1293, Japan

2 The OCU Advanced Research Institute for Natural Science and Technology (OCARINA), Osaka City University, 3-3-138 Sugimoto, Sumiyoshi-ku, Osaka 558-8585, Japan;

E-Mail: masukawa@ocarina.osaka-cu.ac.jp

3 Department of Biological Sciences, Kanagawa University, Tsuchiya, Hiratsuka, Kanagawa 259-1293, Japan; E-Mails: pt125536zy@kanagawa-u.ac.jp (M.K.); inouek01@kanagawa-u.ac.jp (K.I.)

* Author to whom correspondence should be addressed; E-Mail: sakurai@waseda.jp; Tel.: +81-463-59-4111; Fax: +81-463-58-9694.

Academic Editors: John C. Meeks and Robert Haselkorn

Received: 5 January 2015 / Accepted: 9 March 2015 / Published: 18 March 2015

\begin{abstract}
Photobiological production of $\mathrm{H}_{2}$ by cyanobacteria is considered to be an ideal source of renewable energy because the inputs, water and sunlight, are abundant. The products of photobiological systems are $\mathrm{H}_{2}$ and $\mathrm{O}_{2}$; the $\mathrm{H}_{2}$ can be used as the energy source of fuel cells, etc., which generate electricity at high efficiencies and minimal pollution, as the waste product is $\mathrm{H}_{2} \mathrm{O}$. Overall, production of commercially viable algal fuels in any form, including biomass and biodiesel, is challenging, and the very few systems that are operational have yet to be evaluated. In this paper we will: briefly review some of the necessary conditions for economical production, summarize the reports of photobiological $\mathrm{H}_{2}$ production by cyanobacteria, present our schemes for future production, and discuss the necessity for further progress in the research needed to achieve commercially viable large-scale $\mathrm{H}_{2}$ production.
\end{abstract}

Keywords: cyanobacteria; hydrogen; photosynthesis; nitrogenase; heterocyst; renewable energy; mariculture 


\section{Introduction}

\subsection{Global Climate Change}

The concentration of atmospheric $\mathrm{CO}_{2}$ has been increasing since the era of the industrial revolution when it was estimated to be $270-280 \mathrm{ppm}$ initially, rising to current levels of about $400 \mathrm{ppm}$. According to the fifth assessment report of the UN IPCC (United Nations Intergovernmental Panel on Climate Change) [1,2], the greatest contribution to the global increase in greenhouse gases comes from $\mathrm{CO}_{2}$ emitted by burning fossil fuels (65\%) and land use changes (deforestation) (11\%), followed by methane $(16 \%), \mathrm{N}_{2} \mathrm{O}(6 \%)$ and fluorocarbons, etc. (2\%). Currently, the amounts of greenhouse gases emitted have continued to rise due to the increases in human activities and population growth. If we are able to stabilize the atmospheric greenhouse gases at 530-580 ppm- $\mathrm{CO}_{2}$ equivalent (approximately twice that of the pre-industrial level), one of the ICPP scenarios predicts that we will need to reduce global greenhouse gas emissions by $19 \%-47 \%$ in 2050 and $59 \%-81 \%$ in 2100 (relative to 2010 emissions) (Figure 1). Some scenarios predict that we will need to go beyond reduction strategies and achieve "negative emissions" by $\mathrm{CO}_{2}$ sequestration, etc. Economically advanced countries will likely be required to reduce emissions the most, perhaps by as much as $80 \%$ compared to present levels. Even if we succeed in stabilizing greenhouse gases at the level of $530-580$ ppm $\mathrm{CO}_{2}$ equivalent, the global average temperature will rise around $2.0-2.2{ }^{\circ} \mathrm{C}$ relative to the $1850-1900$ temperatures. Stabilizing emissions at a less-stringent level of $720-1000 \mathrm{ppm}-\mathrm{CO}_{2}$ equivalent, would still require substantial emissions reduction from current, largely unregulated levels, and result in the average temperature rising around 3.1-3.7 ${ }^{\circ} \mathrm{C}$ relative to the $1850-1900$ temperatures. From all of these considerations, it is evident that we urgently need viable renewable energy technologies as part of a global strategy to drastically reduce $\mathrm{CO}_{2}$ emissions from burning fossil fuels and thus avert potentially catastrophic climate change.

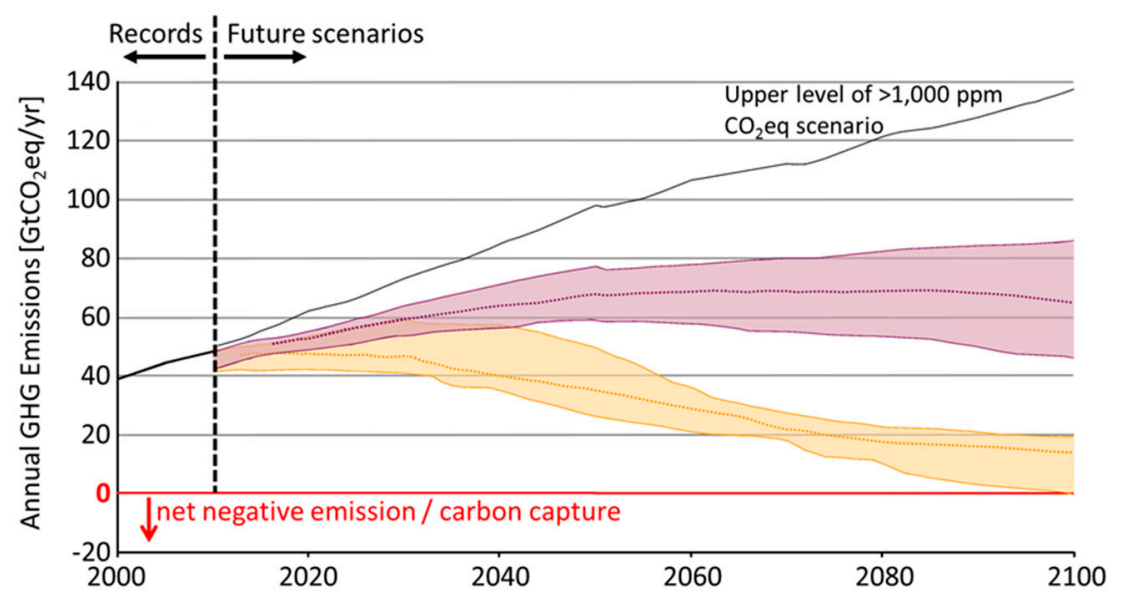

Figure 1. Some scenarios for annual greenhouse gas (GHG) emission, UN IPCC. Due to uncertainty regarding future emissions and prediction of the outcome, probable ranges are shown for each stabilization targets. Stabilization at 530-580 and 720-1000 ppm $\mathrm{CO}_{2}$-eq respectively in 2100. The upper level of the probable range of $>1000 \mathrm{ppm} \mathrm{CO}_{2}$-eq line in IPCC scenario is also shown. (Adapted from Figure SPM4, IPCC, 2014: Summary for Policy Makers, the Climate Change 2014 [1]). 


\subsection{Prospects for Large-Scale Algal Biofuel Production}

We are currently consuming energy at an unsustainably high rate, with much of the consumption (about 82\%) coming from fossil fuels (Table 1) (International Energy Agency (IEA), IEA 2014) [3]. Land-based production of biofuels has been proposed to meet at least some of our energy needs. One method for assessing the energy potential of land-based production systems is to consider total primary energy consumption in the context of the nutritional energy consumption largely derived from current land-based crop systems. In terms of total primary energy consumption, on a world-wide average, people consume about 25 times their nutritional energy (20 times, compared with the fossil fuel-derived energy) (Table 1): people in US 100, Germany 56, Japan 52, China 31 times, respectively (IEA Energy Indicators 2012 in (IEA Key World Energy Statistics 2014)) [4]. From this comparison, it is evident that we cannot expect much more additional energy from land-based agricultural crops, such as sugar cane and corn. Accordingly, there are growing interests in the development and production of biofuels, such as biomass, biodiesel, and $\mathrm{H}_{2}$, using a variety of microalgae grown on lands that are not suitable for agricultural production [5-9]. However, commercially viable large-scale fuel production from microalgae has yet to be realized.

Table 1. Solar energy and human energy consumption.

\begin{tabular}{|c|c|c|c|c|c|}
\hline & $\begin{array}{c}\text { Energy Intensity } \\
\text { and Quantity }\end{array}$ & & Ratios & & $\begin{array}{c}\text { Refs./ } \\
\text { Remarks }\end{array}$ \\
\hline \multicolumn{6}{|c|}{ Solar energy received on Earth surface } \\
\hline Intensity & $\begin{array}{c}165 \mathrm{~W} \cdot \mathrm{m}^{-2} \\
\left(1450 \mathrm{kWh} \cdot \mathrm{m}^{-2} \cdot \mathrm{yr}^{-1}\right)\end{array}$ & & & & {$[10]$} \\
\hline Total energy & $2,660,000 \times 10^{18} \mathrm{~J} \cdot \mathrm{yr}^{-1}$ & 4750 & 5800 & 440,000 & {$[10]$} \\
\hline $\begin{array}{l}\text { Photosynthetically } \\
\text { active radiation }\end{array}$ & $1,200,000 \times 10^{18} \mathrm{~J} \cdot \mathrm{yr}^{-1}$ & & & & $45 \%$ of the total \\
\hline \multicolumn{6}{|c|}{ Human social energy consumption } \\
\hline Total primary energy supply & $560 \times 10^{18} \mathrm{~J} \cdot \mathrm{yr}^{-1}$ & 1 & 1.22 & 25 & {$[3]$} \\
\hline Fossil fuel consumption & $460 \times 10^{18} \mathrm{~J} \cdot \mathrm{yr}^{-1}$ & 0.82 & 1 & 21 & {$[3]$} \\
\hline $\begin{array}{l}\text { Human digestive energy } \\
\text { intake }\end{array}$ & $22 \times 10^{18} \mathrm{~J} \cdot \mathrm{yr}^{-1}$ & 0.039 & 0.048 & 1 & $\begin{array}{c}\text { Population: } 7.2 \times 10^{9} \\
2000 \mathrm{kcal} \cdot \mathrm{capita}^{-1} \cdot \mathrm{day}^{-1}\end{array}$ \\
\hline
\end{tabular}

\subsection{Examples of Policies to Promote the Development of Renewable Energy Technologies}

\subsubsection{Feed-In Tariff Scheme in Germany}

Feed-in electricity tariffs were introduced in Germany in 2004 to encourage the use of new energy technologies, such as wind, hydro- and geo-thermal power, biomass, and solar photovoltaics. Feed-in tariffs are a policy employed by governments to encourage investment in renewable energy technologies by providing them a fee (or "tariff") above the retail rate of electricity. Feed-in tariffs provide long-term investment security to renewable energy producers and are typically based on the costs of specific technology. Wind power, for instance, costs less to produce than solar PV or tidal powers, so the tariff awarded is correspondingly lower. In a Wikipedia entry [11], the German feed-in tariff system is described as one of the most efficient and effective support schemes in the world for promoting 
renewable electricity. As of August 2014, a revised Renewable Energy Sources Act (EEG 2014, also called EEG 2.0) was implemented in Germany, with some modifications to the feed-in tariffs. The aim is to meet Germany's renewable energy goals of $40 \%$ to $45 \%$ of electricity consumption in 2025 and $55 \%$ to $60 \%$ in 2035 [12].

For an international comparison of the price of energy and feed-in tariff, the following currency exchange rates (approximate average currency exchange rates in 2014) were assumed in this paper: 1 Euro $=132$ US $\phi$, and 100 Japanese Yen $=94$ US $\phi$. The German feed-in tariffs in August of 2014 are: 4.62 US $\notin / \mathrm{kWh}$ for hydropower facilities up to $50 \mathrm{MW}, 16.5 \phi / \mathrm{kWh}$ for those up to $500 \mathrm{kWh}, 16.4 \notin / \mathrm{kWh}$ for solar installations on buildings up to $10 \mathrm{~kW}$ and $25.6 \notin / \mathrm{kWh}$ for offshore wind [12]. The tariffs for photovoltanics in 2014 decreased by about 80\% compared with those in 2004, the starting year of the German program, demonstrating the effectiveness of the policy strategy.

\subsubsection{Feed-In Tariff Scheme in Japan [13]}

The government of Japan introduced feed-in tariffs in 2012. In April 2014, the purchase prices (excluding the tax, with the purchase period of 10 or 20 years at fixed prices) were: $34.8 \phi / \mathrm{kWh}$ for photovoltanics up to $10 \mathrm{kWh}, 30.1 \notin / \mathrm{kWh}$ for those $10 \mathrm{~kW}$ or more, $20.7 \phi / \mathrm{kWh}$ for land-based wind power, $33.8 \notin / \mathrm{kWh}$ for offshore wind power, and 13.2 $\mathrm{c} / \mathrm{kWh}$ for medium hydropower. Because the prices offered by the government were so favorable to investors, in southern Japan, Kyushu Electric Power Co. had to suspend receipt of applications from large-sized renewable-energy producers (photovoltanics) wishing to access the company's grid while it reviews how much more clean energy it's capable of handling on sunny days.

\subsubsection{Estimated Cost of Electricity in the USA}

According to the 2012 estimates by the US Energy Information Administration (eia), the levelized cost of electricity in $\phi / \mathrm{kWh}$ for plants entering service in 2019 are: conventional coal 9.56 (no subsidy), geothermal 4.79 (4.45, with subsidy), solar photovoltanic 13.0 (11.86 with subsidy), etc. [14]. These estimates illustrate that for the US, coal continues to be a relatively cheap source of electricity even though burning coal emits a large amount of $\mathrm{CO}_{2}$ into the atmosphere. In order to decrease $\mathrm{CO}_{2}$ emissions from coal, the integrated coal-gasification combined cycle (IGCC) (estimated to be $11.59 \phi / \mathrm{kWh}$ ) and IGCC with carbon control and sequestration (CCS) systems have been proposed (estimated to be $14.74 \phi / \mathrm{kWh}$ ). The $\mathrm{CO}_{2}$ captured in these systems is transported to a storage site, normally an underground geological formation. The effectiveness of CCS, and its long-term effects on the environment need to be carefully assessed.

\subsubsection{Possible Merit of $\mathrm{H}_{2}$ as Motor Fuels}

The next-generation of fuel-efficient cars is entering the consumer market. Toyota recently announced the commercialization of hydrogen fuel-cell vehicles called "Mirai" in December 2014 [15]. According to Toyota, using measurements based on the Japanese JC08 test cycle, a cruising range of approximately $700 \mathrm{~km}$ can be achieved when fueled with $\mathrm{H}_{2}$ at $70 \mathrm{MPa}$. In comparison, the cruising ranges of electric cars might be around 100-200 km per full battery charge. In the same month, several Japanese 
gas companies announced opening commercial hydrogen refueling stations with the introductory prices of $\mathrm{H}_{2}$ (subsidized by the government) ranging from 9.4 to 10.3 US\$ (1000-1100 Japanese Yen) per kg, or $23.8-26.1 \notin / \mathrm{kWh}[16]$. Because the energy efficiency of fuel cell cars is better than internal combustion engine cars, it is estimated that $\mathrm{H}_{2}$ fuel will be competitive with gasoline 1.22-1.60 US $\$ / \mathrm{L}$ (retail price of about $13.9-18.3 \notin / \mathrm{kWh}$ including tax, calculated on an energy density of $8.76 \mathrm{kWh} / \mathrm{L}$ ).

\section{Outline of the Biological Processes of Photobiological $\mathrm{H}_{2}$ Production by Heterocyst-Forming Cyanobacteria}

Photobiological production of biomass by photosynthetic organisms (trees, grasses, algae, etc.) is considered one of the better candidates for large-scale, renewable energy because the amount of solar energy is almost infinite (Table 1). Photobiological $\mathrm{H}_{2}$ production by cyanobacteria is one of the options, and this review briefly discusses nitrogenase ( $\mathrm{N}_{2}$ ase)-based photobiological $\mathrm{H}_{2}$ production by cyanobacteria because it is the focus of our current studies. In doing so, we do not intend to supplant other systems, such as hydrogenase ( $\mathrm{H}_{2}$ ase)-based photobiological $\mathrm{H}_{2}$ production by various algae including cyanobacteria, as well as biofuel production (e.g., biomass, biodiesel) by various photosynthetic microorganisms.

Some strains of cyanobacteria possessing $\mathrm{N}_{2}$ ase are good candidates for optimization of photobiological $\mathrm{H}_{2}$ production [17-21]. N2ase catalyzes the following reaction under optimal conditions for $\mathrm{N}_{2}$ fixation:

$$
\mathrm{N}_{2}+8 \mathrm{e}^{-}+8 \mathrm{H}^{+}+16 \mathrm{ATP} \rightarrow \mathrm{H}_{2}+2 \mathrm{NH}_{3}+16\left(\mathrm{ADP}+\mathrm{P}_{\mathrm{i}}\right)
$$

whereas, in the absence of $\mathrm{N}_{2}$ (e.g., under $\mathrm{Ar}$ ), all $\mathrm{e}^{-} \mathrm{s}$ are allocated to $\mathrm{H}_{2}$ production:

$$
2 \mathrm{e}^{-}+2 \mathrm{H}^{+}+4 \mathrm{ATP} \rightarrow \mathrm{H}_{2}+4\left(\mathrm{ADP}+\mathrm{P}_{\mathrm{i}}\right)
$$

The above reactions catalyzed by $\mathrm{N}_{2}$ ase are essentially irreversible. $\mathrm{N}_{2}$ ase is extremely $\mathrm{O}_{2}$ sensitive and quickly inactivated by $\mathrm{O}_{2}$. In order to reconcile the activities of the $\mathrm{O}_{2}$-sensitive $\mathrm{N}_{2}$ ase with $\mathrm{O}_{2}$-evolving photosynthesis, cyanobacteria have evolved various means to address to the physiological challenges [22]. There are three basic groups. In Group 1, the two processes are separated spatially as found in heterocystous filamentous types (e.g., Anabaena, Nostoc, Calothrix). In Group 2, the processes are separated temporally by circadian rhythm as found in non-heterocystous unicellular and filamentous types (e.g., Cyanothece, Lyngbya). In Group 3, other non-heterocystous filamentous types (e.g., Trichodesmium) seem to sporadically perform the two processes: some of the cells have ordinary $\mathrm{O}_{2}$-evolving photosynthesis activity, while the others temporally cease photosynthesis and fix $\mathrm{N}_{2}$ [23].

In this review, we will discuss mainly Group 1 cyanobacteria, as these strains are the focus of our research and because they are the most extensively studied among the three groups with respect to physiology, molecular biology, etc. [24-26]. The cells are organized as filaments, with the majority of the cells (called vegetative cells) synthesizing organic compounds by ordinary photosynthesis. Under combined-nitrogen deficiency a few of the cells develop into heterocysts, cells specialized for nitrogen fixation. Heterocysts lacking photosystem II activity, have increased respiration and are surrounded by a thick cell envelope that impedes the entry of $\mathrm{O}_{2}$, thus providing a micro-oxic environment to protect the $\mathrm{N}_{2}$ ase from inactivation by $\mathrm{O}_{2}$. They receive saccharides from neighboring vegetative cells and the saccharides are then used as the electron donors for the $\mathrm{N}_{2}$ ase reaction (Figure 2). Within heterocysts, 
photosystem I reduces low-potential ferredoxin and/or flavodoxin and contributes to the generation of ATP through photophosphorylation. The fixed nitrogen is converted to glutamine, which is transported to vegetative cells. In this manner, heterocystous cyanobacteria are able to simultaneously perform $\mathrm{O}_{2}$-evolving photosynthesis and the $\mathrm{O}_{2}$-labile $\mathrm{N}_{2}$ ase reaction.

Many of these types of cyanobacterial strains have the uptake hydrogenase (Hup) and some (but not all) of them also have the bidirectional hydrogenase (Hox) [27-29]. The former $\mathrm{H}_{2}$ ase reabsorbs $\mathrm{H}_{2}$ produced by $\mathrm{N}_{2}$ ase and thus the presence of Hup activity can limit the net production of $\mathrm{H}_{2}$ by the $\mathrm{N}_{2}$ ase. There has been a report of an environmental isolate of the non-heterocystous Oscillatoria sp. strain Miami BG7 that lacks Hup activity and is able to accumulate $\mathrm{H}_{2}$ in the presence of photosynthetically evolved $\mathrm{O}_{2}$ [30]. When Hup activity was eliminated by molecular genetic techniques [28,31-36] or chemical mutagenesis [37], the resulting cyanobacterial mutants showed enhanced $\mathrm{H}_{2}$ production activity. Since in contrast to $\mathrm{H}_{2}$ ase activity, $\mathrm{N}_{2}$ ase catalyzes an essentially unidirectional $\mathrm{H}_{2}$ production and thus does not consume $\mathrm{H}_{2}$, cyanobacterial mutants lacking Hup activity are able to accumulate $\mathrm{H}_{2}$ to about $7 \%-30 \%(\mathrm{v} / \mathrm{v})$ in the presence of $\mathrm{O}_{2}$ evolved $[35,38]$.

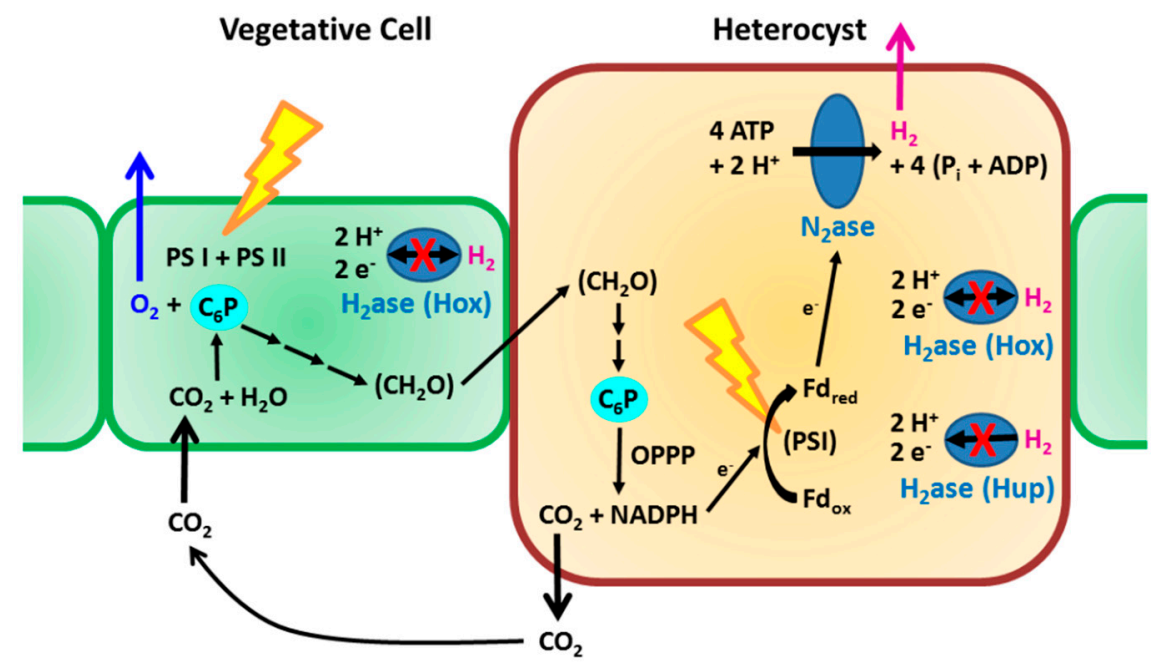

Figure 2. Outline of $\mathrm{H}_{2}$-related metabolic routes in heterocyst-forming cyanobacteria. Vegetative cells synthesize saccharides $\left(\mathrm{CH}_{2} \mathrm{O}\right)$ by ordinary photosynthesis with accompanying evolution of $\mathrm{O}_{2}$ and uptake of $\mathrm{CO}_{2}$. Heterocysts receive the saccharides, and use them (accompanied by $\mathrm{CO}_{2}$ evolution) as the sources of $\mathrm{e}^{-}$for $\mathrm{N}_{2}$ ase reaction. For efficient net production of $\mathrm{H}_{2}, \mathrm{H}_{2}$ ase(s) (uptake $\mathrm{H}_{2}$ ase Hup and bidirectional $\mathrm{H}_{2}$ ase Hox) have been inactivated. $\mathrm{C}_{6} \mathrm{P}$ : hexose phosphate, $\mathrm{Fd}_{\mathrm{ox}}$ and $\mathrm{Fd}_{\mathrm{red}}$ : ferredoxin oxidized and reduced respectively, OPPP: oxidative pentose phosphate pathway, PSI and PSII: photosystem I and II, respectively (adapted from [21] with modification).

In the unicellular diazotrophic cyanobacterium Cyanothece sp. strain PCC 7822, the $\mathrm{N}_{2}$ ase and $\mathrm{H}_{2}$ production activities are inactivated following disruption of the $h u p L$ gene (encoding a large subunit of Hup) via molecular genetic techniques, indicating that Hup protects $\mathrm{N}_{2}$ ase from oxygen toxicity by removing $\mathrm{O}_{2}$ in this strain [39]. 
Although Hup may play such a role, the degree of its $\mathrm{N}_{2}$ ase protection may differ among strains, and we can selectively use the strains (either heterocystous or unicellular) in which the negative effects of elimination of Hup on net $\mathrm{H}_{2}$ production are low.

\section{Some Lessons from Studies of the Economics of Large-Scale Algal Fuel Production}

\subsection{Benemann's Critical View of Algal Biofuel Production}

Benemann has been studying photobiological biofuel production by various algae, since the first discovery of $\mathrm{N}_{2}$ ase-based photobiological $\mathrm{H}_{2}$ production by cyanobacteria [40]. He critically examined the viability of microalgae for the production of gaseous fuels, specifically $\mathrm{H}_{2}$ and $\mathrm{CH}_{4}$, and assessed various proposed schemes on the basis of their technological and economic feasibility. In 2004, he summarized his opinion [41] as: "Processes for the production of gaseous fuels, $\mathrm{H}_{2}$ and $\mathrm{CH}_{4}$, using microalgae culture have been studied from a scientific perspective for several decades, and the practical cultures have been studied relatively recently. The lack of practical results in $\mathrm{H}_{2}$ and $\mathrm{CH}_{4}$ production cannot be ascribed to limited $R \& D$ funding. The only present practical application is the harvesting of algal biomass from wastewater treatment ponds by chemical flocculation, followed by the anaerobic digestion of the algal biomass. Overall, costs of such a process were estimated at about $\$ 10$ per GJ of $\mathrm{H}_{2}$ (3.6 غ/kWh)." Benemann's conceptual steps for a techno-economic analysis consisted of: (1) Production in open ponds (costing $\$ 7 \mathrm{~m}^{-2}, 0.5 \mathrm{~km}^{2}$ in area in some of his analyses), at a solar efficiency of $10 \%$, of a nitrogen-limited biomass (that accumulates large amounts of storage carbohydrates); (2) Concentration of the biomass from the ponds in a settling pond; (3) Anaerobic dark fermentation to yield $4 \mathrm{H}_{2} / g l u c o s e$ stored in the algal cells, plus two acetate moles; and (4) Reaction in a photobioreactor in which the algal cells would be converted from the two acetate moles to eight moles of $\mathrm{H}_{2}$. The cost of the process was estimated at about $\$ 10$ per $\cdot \mathrm{GJ}^{-1}$ of $\mathrm{H}_{2},(3.6 \varnothing / \mathrm{kWh})$ with the photobioreactor comprising about half of the total cost. In our opinion, a photosynthesis efficiency of $10 \%$, required for economical production, is very difficult to attain even if an algal $\mathrm{H}_{2}$ ase serving as a highly efficient $\mathrm{H}_{2}$ catalyst is used.

\subsection{Life-Cycle Analysis (LCA) of the Energy Requirements for Algal Fuel Production}

Clarens et al. [42] made LCA analyses of biofuel production by microalgae based on published records (first-generation algae production), and found that algae production systems release more $\mathrm{CO}_{2}$ to the atmosphere than is taken up during growth of the biomass. Their schemes are: (1) Growth of algae in open ponds using a raceway configuration, with slow-moving paddle wheels to aerate and circulate the algae growth medium; (2) fertilizers are added as water is pumped in to or out of (for harvesting) the ponds; and (3) $\mathrm{CO}_{2}$ is bubbled into the ponds. The result of the analyses for a production site in California, for example, indicated that for producing 1.00 unit of energy, about 1.18 unit of energy is consumed; nutrients: 0.49 unit (about 0.2 unit for urea), $\mathrm{CO}_{2}$-derived: 0.35 unit, direct: 0.04 unit, and others (water, etc.): 0.29 unit. They pointed out that in addition to anticipated improvements in algal productivity (next-generation production), the uses of flue gas (from coal fired plants) and municipal wastewater (to reduce nutrient energy costs) could lead to a net-positive bioenergy production by microalgae in these systems. 


\subsection{Life-Cycle Analysis (LCA) of the Costs for Large-Scale Microalgal Production}

A comparative LCA study of the potential environmental impact and economic viability of producing biodiesel from microalgae grown in large virtual ponds $\left(4 \mathrm{~km}^{2}\right)$ of coastal Australian land were made [43]. In terms of GHG (greenhouse gas) emissions, algae GHG (-27.6 to $18.2\left(\mathrm{CO}_{2}\right.$-unit)) compare very favorably with canola (35.9) and ultra-low sulfur (ULS) diesel from oil (81.2). Costs are not so favorable, with algae ranging from 2.2 to 4.8 (cost-unit), compared with canola (4.2) and ULS diesel (3.8). The large footprint of algae cultivation is driven predominantly by upstream factors, such as the demands for $\mathrm{CO}_{2}$ and fertilizer. To reduce these factors, flue gas and, to a greater extent, municipal waste-water could be used to offset the economic and environmental burdens associated with algae, highlighting the need for a high production rate to make algal biodiesel economically attractive.

\section{Our Scheme for Large-Scale Photobiological $\mathrm{H}_{2}$ Production by Mariculture-Raised Cyanobacteria}

We briefly discuss several issues for achieving commercially viable large-scale photobiological $\mathrm{H}_{2}$ production by cyanobacteria. Photobiological $\mathrm{H}_{2}$ production is considered to be one of the better candidates for renewable energy production because $\mathrm{H}_{2}$ pollutes environment minimally both in production as well as in utilization stages, and is relatively easily storable and transportable.

We will first describe an outline of our conceptual scheme [44] for large-scale photobiological $\mathrm{H}_{2}$ production by mariculture-raised cyanobacteria. We will then discuss some of the key issues in greater detail. Our scheme is: (1) Production of $\mathrm{H}_{2}$ in large plastic bioreactors consisting of several layers of plastic film; (2) repeated harvesting of crude $\mathrm{H}_{2}$; (3) initial separation of $\mathrm{H}_{2}$ from $\mathrm{O}_{2}$ possibly by gas-selective permeability membranes on factory ships followed by further purification of $\mathrm{H}_{2}$ by pressure-swing adsorption (PSA); and (4) compression or transformation to a form suitable for transportation by ship and storage (Figures 3 and 4).

Table 2. Expected sales of photobiologically produced $\mathrm{H}_{2}$.

\begin{tabular}{cccccccc}
\hline \multirow{2}{*}{$\begin{array}{c}\text { Energy } \\
\text { Conversion } \\
\text { Efficiency }(\%)\end{array}$} & $\begin{array}{c}\text { Produced } \mathrm{H}_{2} \\
\left(\mathrm{kWh} \cdot \mathrm{m}^{-2} \cdot \mathrm{yr}^{-1}\right)\end{array}$ & $\begin{array}{c}\text { Energy } \\
\text { Recovery } \\
(\text { Ratio })\end{array}$ & $\begin{array}{c}\text { Purified } \mathrm{H}_{2} \\
\left(\mathrm{kWh} \cdot \mathrm{m}^{-2} \cdot \mathrm{yr}^{-1}\right)\end{array}$ & \multicolumn{3}{c}{$\mathbf{H}_{\mathbf{2}}$ Total Sale (cents $\left.\mathbf{~}^{-\mathbf{2}} \cdot \mathbf{y r}^{-1}\right)$} \\
\cline { 5 - 8 } & 15 & 0.3 & 4.5 & 10 & 20 & 30 & 40 \\
\hline 1 & 15 & 0.5 & 7.5 & $\mathbf{4 5}$ & $\mathbf{9 0}$ & $\mathbf{1 3 5}$ & $\mathbf{1 8 0}$ \\
\hline 1 & 15 & 0.7 & 10.5 & $\mathbf{1 0 5}$ & $\mathbf{2 1 0}$ & $\mathbf{3 1 5}$ & $\mathbf{4 2 0}$ \\
\hline 1 & 30 & 0.3 & 9 & $\mathbf{9 0}$ & $\mathbf{1 8 0}$ & $\mathbf{2 7 0}$ & $\mathbf{3 6 0}$ \\
\hline 2 & 30 & 0.5 & 15 & $\mathbf{1 5 0}$ & $\mathbf{3 0 0}$ & $\mathbf{4 5 0}$ & $\mathbf{6 0 0}$ \\
\hline 2 & 30 & 0.7 & 21 & $\mathbf{2 1 0}$ & $\mathbf{4 2 0}$ & $\mathbf{6 3 0}$ & $\mathbf{8 4 0}$ \\
\hline 2 & 45 & 0.3 & 9 & $\mathbf{1 3 5}$ & $\mathbf{2 7 0}$ & $\mathbf{4 0 5}$ & $\mathbf{5 4 0}$ \\
\hline 3 & 45 & 0.5 & 15 & $\mathbf{2 2 5}$ & $\mathbf{4 5 0}$ & $\mathbf{6 7 5}$ & $\mathbf{9 0 0}$ \\
\hline 3 & 45 & 0.7 & 21 & $\mathbf{3 1 5}$ & $\mathbf{6 3 0}$ & $\mathbf{9 4 5}$ & $\mathbf{1 2 6 0}$ \\
\hline 3 & 15 & & & &
\end{tabular}

The $\Delta H$ of $1 \mathrm{~kg}$ crude oil (Oeq) is $41.9 \mathrm{MJ}$ or $11.6 \mathrm{kWh}$ (HHV, higher heating value: the product water is condensed liquid). The $\Delta H$ of $1 \mathrm{~m}^{3}$ (STP) $\mathrm{H}_{2}$ is $12.8 \mathrm{MJ}, 3.56 \mathrm{kWh}$, or $0.30 \mathrm{~kg} \cdot$ Oeq (Oil equivalent) and that of $1 \mathrm{~kg}$ of $\mathrm{H}_{2}$ is $142 \mathrm{MJ}, 39.4 \mathrm{kWh}$ or $3.39 \mathrm{~kg}$ Oeq (HHV). 
Assuming the total solar radiation of about $1500 \mathrm{kWh} \cdot \mathrm{m}^{-2} \cdot \mathrm{yr}^{-1}[10]$ and an energy conversion efficiency of $1 \%-3 \%$ (of total radiation), which will be discussed later, the energy produced as crude $\mathrm{H}_{2}$ is $15-45 \mathrm{kWh} \cdot \mathrm{m}^{-2} \cdot \mathrm{yr}^{-1}$ (Table 2). Assuming an energy recovery ratio (energy in purified $\mathrm{H}_{2}$ /energy in crude $\mathrm{H}_{2}$ ) of $0.3-0.7$, we calculated a total price for $\mathrm{H}_{2}$ of $10-40 \phi / \mathrm{kWh}$ ( $c f$. Section 1.3 for the price ranges of renewable fuels). Table 2 gives sales projections for photobiologically produced $\mathrm{H}_{2}$ and the energy conversion efficiency targets that will promote the adoption of photobiological renewable production.

\subsection{Flexible Plastic Bioreactors Floating on the Surface of Sea Could Reduce Costs}

Bioreactors for commercially viable algal biomass or liquid fuel production should be large (a total of a few $\mathrm{km}^{2}$ as a production unit) and inexpensive. Currently, open ponds with raceway configurations are the leading candidates for the first step of biomass production of algae. For $\mathrm{H}_{2}$ production, closed bioreactors are required in at least some part of the process. A variety of closed hard panel or tubular photobioreactors are described for laboratory or pilot-scale studies (e.g., [45,46]), but they are likely much more expensive than open ponds.

We have proposed flexible $\mathrm{H}_{2}$-barrier plastic bags floating on the calm sea or ocean surface (e.g., the calm belt about $30^{\circ}$ north or south, such as the "mysterious Bermuda triangle" region) [17,44]. The culture medium is based on freshwater, and the bioreactors would spread over the sea surface because of the difference in density between the culture medium and the surrounding seawater. Salt lakes can also be used as the fields for cultivation. The size of the bags is flexible; for large-scale $\mathrm{H}_{2}$ production for example, 20 bags of $25 \mathrm{~m} \times 200 \mathrm{~m}$ in surface area, could cover the surface of $1 \mathrm{~km}^{2}$. As proof of this concept, Kitashima et al. [47] demonstrated that transparent flexible $\mathrm{H}_{2}$-barrier plastic bags are usable for studies of photobiological $\mathrm{H}_{2}$ production by cyanobacteria in the laboratory. The $\mathrm{H}_{2}$ permeability $\left(\mathrm{P}_{\mathrm{m}}\right)$ value of the transparent plastic bags ranged from 44 to $87 \mathrm{~cm}^{3} \cdot \mathrm{m}^{-2} \cdot \mathrm{atm}^{-1} \cdot \mathrm{day}^{-1} \cdot \mathrm{H}_{2}$-barrier bags for laboratory use (Wakhy bags, www.ab.auone-net.jp/ wakhylab) are now commercially available (GL Sciences, Tokyo.info@gls.co.jp).

The cost of the bioreactor was estimated as follows [44]. The bioreactor is composed of three layers of plastic bags (Figure 3), for a total of six layers (sunny side and shady side) of transparent plastic film. The innermost bag holds the cyanobacteria culture, the middle bag has very low permeability to $\mathrm{H}_{2}$, and the outermost bag serves to mechanically protect the inner bags. The thickness of each film is $0.08 \mathrm{~mm}$, and $480 \mathrm{~cm}^{3}$ of plastic per $\cdot \mathrm{m}^{2}$ of the bioreactor's sunny side surface is required. Assuming an average plastic price of \$2-\$4 per $\mathrm{kg}$ (or liter), the material cost is $96-192$ cents $\cdot$ per $\cdot \mathrm{m}^{2}$ of bioreactor. The used plastic bags can be recycled many times to regenerate plastic films at about half the price of the new materials. The above assumptions result in the cost of the bioreactor being about $24-48$ cents per $\cdot \mathrm{m}^{2}$ of bioreactor surface per year, assuming a renewal cycle of every two years. The plastic films of $480 \mathrm{~cm}^{3}$ are assumed to be produced by consuming $360 \mathrm{~mL}$ of crude oil for processing that is equivalent to $3.92 \mathrm{kWh} \cdot$ per $\cdot \mathrm{m}^{2}$ per year. The plastic bags can be recycled at an energy cost of $20 \%$ of the feedstocks $(0.78 \mathrm{kWh})$. The amount of energy in feedstocks derived from fossil fuels can be further decreased because currently $\mathrm{H}_{2}$ generated from fossil fuels is used as a part of the feedstocks for plastic film production, and photobiologically-produced $\mathrm{H}_{2}$ can replace some part of it. 


\subsection{Cost-Effective Strategy for Achieving Adequate Cell Growth with Repeated Harvesting of $\mathrm{H}_{2}$ without Changing the Culture Medium}

Under our proposed strategy, $\mathrm{H}_{2}$ ase-less mutant cyanobacterial cells grow in large ordinary plastic bags containing $\mathrm{CO}_{2}$ (with its occasional replenishment) floating on the sea without mechanical agitation of the medium (Step 1, in Figure 3). The need for additional combined nitrogen for growth would be minimal and thus the cost of fertilizer would be much less as compared to systems using non-nitrogen-fixing microalgae. Cyanobacterial stock cultures are transferred to photobioreactors for $\mathrm{H}_{2}$ production (Step 2). The innermost bag (Figure 3) is filled with gas containing $\mathrm{CO}_{2}$ in Ar. In the $\mathrm{H}_{2}$ production stage, no mechanical agitation or bubbling are applied, as $\mathrm{CO}_{2}$ is recycled within the bag (absorbed during photosynthetic carbon assimilation in vegetative cells and released from heterocysts when saccharides are degraded as electron donors to $\mathrm{N}_{2}$ ase (Figure 2)). The cyanobacterial cell waste can be recycled as fish feed [48].

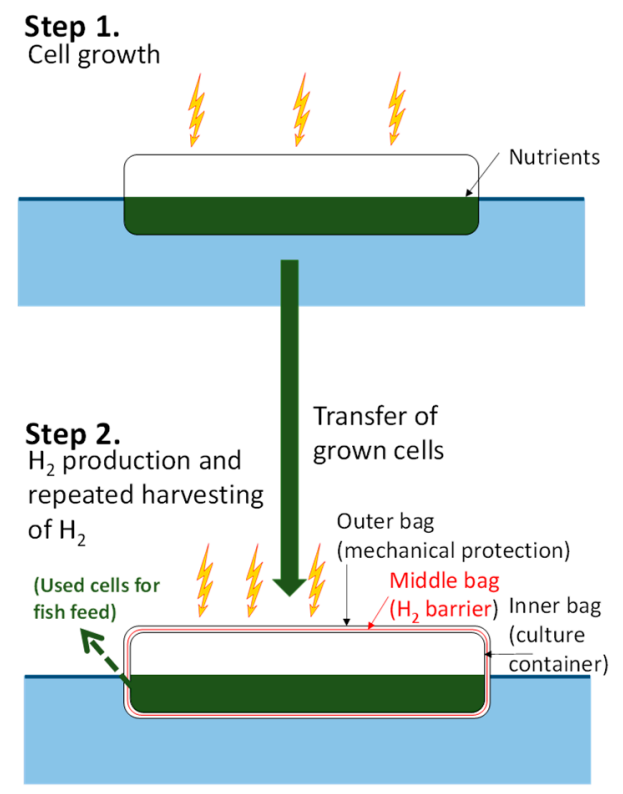

Figure 3. Outline of $\mathrm{H}_{2}$ production by mariculture-raised cyanobacteria. Step 1: Cell growth in a transparent plastic bag floating on the sea surface. The bioreactor is filled with air containing $\mathrm{CO}_{2}$; Step 2: $\mathrm{H}_{2}$ production in a photobioreactor composed of three bags (at least one layer is a $\mathrm{H}_{2}$ gas barrier membrane) floating on the sea surface. The spent cells can be used as fish feed [48].

The proposed strategy can be modified in response to changes in production costs. For example, when the cost of $\mathrm{Ar}$ is high, $\mathrm{N}_{2}$ ase mutants can be used [49]. Some of the mutants have high $\mathrm{H}_{2}$ production activity under $\mathrm{N}_{2}$-rich gas as compared to the parent strain activity under Ar gas, and also have extremely low $\mathrm{N}_{2}$-fixing activity. Examples of such mutants have been characterized; with the amino acid substitutions presumed to be located in the vicinity of the FeMo-cofactor of $\mathrm{N}_{2}$ ase (e.g., Q193S and $\mathrm{R} 284 \mathrm{H}$ ) [49]. The $\mathrm{N}_{2}$ ase activity of such mutants is not inhibited by the presence of high concentrations of $\mathrm{N}_{2}$ and thus the use of costly Ar could be avoided. However, these strains require combined nitrogen in the growth stage, and the advantages and disadvantages of using this type of mutant needs to be carefully assessed. 


\subsection{Initial Separation of crude $\mathrm{H}_{2}$ Followed by Further Purification by Pressure-Swing Adsorption} (PSA) on Factory Ships

The $\mathrm{H}_{2}$ produced within the bag is allowed to accumulate for several weeks to a few months before "harvesting" the gas mixture (Figure 4). After removal of $\mathrm{O}_{2}$ from the harvested gas mixture, $\mathrm{H}_{2}$ is purified on factory ships by PSA (pressure-swing adsorption) for transportation to ports [44]. The separated $\mathrm{Ar}$ and $\mathrm{CO}_{2}$ are recycled back to the bioreactors, along with replenishment of $\mathrm{H}_{2} \mathrm{O}$ (substrate necessary for $\mathrm{H}_{2}$ production) to resume the next round of $\mathrm{H}_{2}$ production. The amount of $\mathrm{H}_{2} \mathrm{O}$ needed is relatively small, $\left(0.8 \mathrm{~kg} \mathrm{H} \mathrm{H}_{2} \mathrm{O}\right.$ is required for $1 \mathrm{~m}^{3} \cdot \mathrm{H}_{2}$, or $18 \mathrm{~g}$ for $\left.22.4 \mathrm{~L} \cdot \mathrm{H}_{2}\right)$. Some of the downstream technologies outlined in Figure 4 are still in the developmental stage, notably the initial separation of $\mathrm{H}_{2}$ from $\mathrm{O}_{2}$ in the gas mixtures. One of the candidate technologies involves the use of gas-selective membranes that allow the penetration of $\mathrm{H}_{2}$ at much higher rates than that of $\mathrm{O}_{2}$. For example, there is a report of a carbon molecular sieve membrane that allows permeation of $\mathrm{H}_{2}$ about 10-15 times faster than $\mathrm{O}_{2}$ (the gas permeability constant of 372-473 and 25-50 in gas permeability units for $\mathrm{H}_{2}$ and $\mathrm{O}_{2}$, respectively) [50]. We expect that there will be a concomitant development of these technologies if photobiological $\mathrm{H}_{2}$ production on the sea surface is adopted as one of the best options for large-scale renewable energy production (an example of "necessity is the mother of invention").

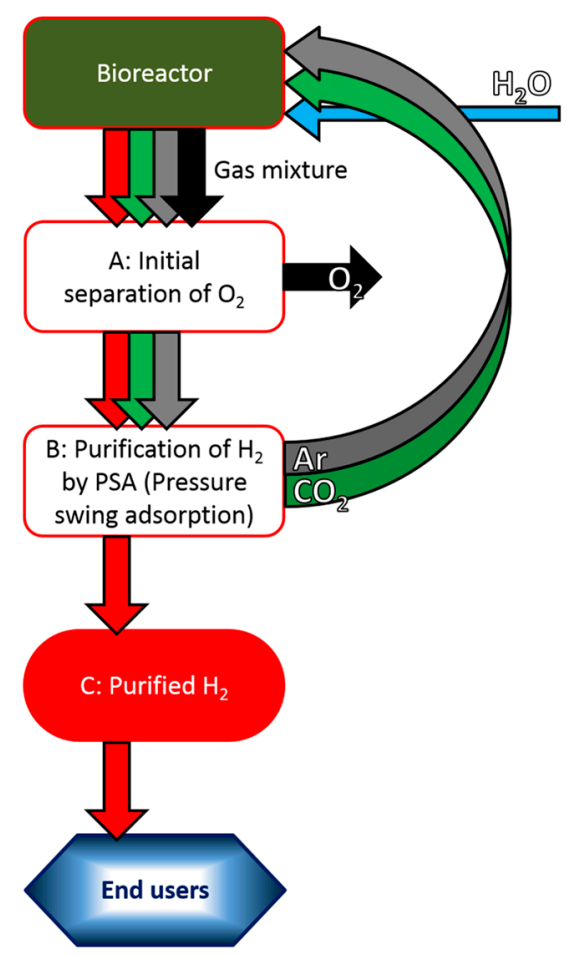

Figure 4. Outline of photobiological $\mathrm{H}_{2}$ production by mariculture-raised cyanobacteria and delivery of purified $\mathrm{H}_{2}$ to end-users (possible scheme). The fully grown cells (Step 1, Figure 3) are transferred to the photobioreactor (Step 2, Figure 3), which is filled with Ar and $\mathrm{CO}_{2}$ ( + trace amount of $\mathrm{N}_{2}$, not shown) and allowed accumulation of the produced gases $\left(\mathrm{H}_{2}\right.$ and $\left.\mathrm{O}_{2}\right)$. (A) Initial separation of $\mathrm{O}_{2}$ from the gas mixture; (B) Further purification of $\mathrm{H}_{2}$ by PSA (pressure-swing adsorption), and the removed $\mathrm{CO}_{2}$ and $\mathrm{Ar}$ are recycled to the bioreactor. $\mathrm{H}_{2} \mathrm{O}$ consumed for $\mathrm{H}_{2}$ production is replenished; (C) Purified $\mathrm{H}_{2}$ is processed for transportation to end-users (for details, see text). 
The purified $\mathrm{H}_{2}$ may be condensed (high pressure or liquefied) or chemically transformed (e.g., to $\mathrm{NH}_{3}$ which can subsequently be used as a fuel rather than fertilizer, or reversible hydrogenation of toluene $\left(\mathrm{C}_{7} \mathrm{H}_{8}\right)$ to methyl cyclohexane $\left.\left(\mathrm{C}_{7} \mathrm{H}_{14}\right)\right)$ for transportation to end-users (Figure 4).

\subsection{The Advantages of Sustained High $\mathrm{H}_{2}$ Production without Changing the Culture Medium}

We would like to emphasize that one of the economic advantages of photobiological $\mathrm{H}_{2}$ production by cyanobacteria is that the culture medium can be used continuously. During the growth stage, cyanobacteria do not produce $\mathrm{H}_{2}$ and the input costs of labor, energy, nutrients, etc. are minimal. A major advantage that the $\mathrm{N}_{2}$ ase-based photobiological $\mathrm{H}_{2}$ production by cyanobacteria systems have over the other types of algal biofuel production systems is that once established, cultures can produce $\mathrm{H}_{2}$ for a long time (several weeks) without changing the culture medium and with multiple rounds of gas harvesting $[49,51,52]$ (Table 3), thus off-setting the initial costs of the cell growth phase. Several groups have reported the duration of active $\mathrm{H}_{2}$ production to be several weeks, and we expect that this could be further extended by carefully managing the culture conditions (Table 3). Attaining sustained high $\mathrm{H}_{2}$ production without changing the culture medium will mitigate costs of nutrients, a criticism raised by Clarens et al. [42] (see Section 3.2).

Table 3. Some records of duration ( $>2$ day) of $\mathrm{H}_{2}$ production activity without changing the culture medium.

\begin{tabular}{|c|c|c|c|c|c|c|c|}
\hline Strains & Light Intensity & $\begin{array}{c}\text { Efficiency } \\
(\%) \\
\end{array}$ & $\begin{array}{c}\text { Light } \\
\text { Energy }\end{array}$ & $\begin{array}{c}\text { Duration } \\
\text { of expt. }\end{array}$ & Gas & Remarks & Refs. \\
\hline $\begin{array}{c}\text { Anabaena } \\
\text { cylindrica } 629\end{array}$ & $\begin{array}{c}4.0 \times 10^{5} \\
\mathrm{erg} \cdot \mathrm{cm}^{-2} \cdot \mathrm{s}^{-1}\end{array}$ & $0.4 \%$ av. & total rad. & $8 \mathrm{~d}$ & $\begin{array}{c}\mathrm{Ar} / \mathrm{CO}_{2}(99.7 / 0.3) \\
\text { gassing }\end{array}$ & $\begin{array}{c}250 \mathrm{~mL} \text { culture: } \\
\text { about } 0.6 \mathrm{~L} \text { gas } / \mathrm{h} \\
\text { Cell density of } 200- \\
260 \mathrm{Klett} \text { units } \\
\text { Periodic addition of } \\
10^{-4} \mathrm{M} \cdot \mathrm{NH}_{4} \mathrm{Cl}\end{array}$ & {$[53]$} \\
\hline $\begin{array}{c}\text { Anabaena } \\
\text { cylindrica } 629\end{array}$ & $32 \mathrm{~W} \cdot \mathrm{m}^{-2}$ & $\begin{array}{c}0.85 \% \\
\max .\end{array}$ & PAR & $6 \mathrm{~d}$ & $\begin{array}{c}\mathrm{Ar} / \mathrm{CO}_{2} \\
(99.5 / 0.5), \text { gassing }\end{array}$ & $\begin{array}{l}0.875 \mathrm{~L} \text { culture: } \\
0.3-0.9 \mathrm{~L} \text { gas } / \mathrm{h}\end{array}$ & {$[54]$} \\
\hline $\begin{array}{c}\text { Anabaena } \\
\text { cylindrica } 629\end{array}$ & $6 \mathrm{~W} \cdot \mathrm{m}^{-2}$ & $0.35 \%$ av. & PAR & $28 \mathrm{~d}$ & $\begin{array}{c}\mathrm{Ar} / \mathrm{CO}_{2} \\
(99.5 / 0.5), \text { gassing }\end{array}$ & $\begin{array}{l}0.875 \mathrm{~L} \text { culture: } \\
0.3-0.9 \mathrm{~L} \text { gas } / \mathrm{h}\end{array}$ & {$[54]$} \\
\hline $\begin{array}{c}\text { Mastigocladus } \\
\text { laminosus NZ-86-m }\end{array}$ & $\begin{array}{c}3.0 \times 10^{4} \\
\mathrm{erg} \cdot \mathrm{cm}^{-2} \cdot \mathrm{s}^{-1} \\
\end{array}$ & $\begin{array}{l}2.7 \% \\
\max .\end{array}$ & PAR & $2-3 d$ & $\begin{array}{c}\mathrm{Ar} / \mathrm{N}_{2} / \mathrm{CO}_{2} \\
(98.5 / 1 / 0.5), \text { gassing }\end{array}$ & $1.2 \mathrm{~L}$ culture & {$[55]$} \\
\hline $\begin{array}{c}\text { Nostoc sp. PCC } 7422 \\
\Delta \text { Hup deficient of } \\
\text { Hup }\end{array}$ & $\begin{array}{c}70 \mu \mathrm{mol} \\
\text { photons } \mathrm{m}^{-2} \cdot \mathrm{s}^{-1}\end{array}$ & $3.7 \%$ av. & PAR & $6 \mathrm{~d}$ & $\begin{array}{c}\mathrm{Ar} / \mathrm{CO}_{2}(9.5 / 5) \\
\text { (no gassing) }\end{array}$ & $6 \mathrm{~mL}$ batch culture & {$[35]$} \\
\hline $\begin{array}{c}\text { Anabaena variabilis } \\
\text { ATCC } 29413\end{array}$ & $32 \mathrm{~W} \cdot \mathrm{m}^{-2}$ & $\begin{array}{c}0.96 \% \text { av. } \\
1.32 \% \\
\text { max. }\end{array}$ & PAR & $8 \mathrm{~d}$ & $\begin{array}{c}\text { Stage 1: Ar, gassing, } \\
\text { Stage 2: air } / \mathrm{CO}_{2} \\
(95 / 5), \text { gassing }\end{array}$ & $\begin{array}{c}\mathrm{H}_{2} \text { producing } \\
\text { activity in stage } 2\end{array}$ & {$[56]$} \\
\hline $\begin{array}{c}\text { Nostoc/Anabaena } \\
\text { sp. PCC } 7120 \Delta \mathrm{Hup}, \\
\text { site-directed N2ase } \\
\text { variants, Q193S and } \\
\text { R284H }\end{array}$ & $\begin{array}{l}90-100 \mu \mathrm{mol} \\
\text { photons } \cdot \mathrm{m}^{-2} \cdot \mathrm{s}^{-1}\end{array}$ & not given & PAR & $21 \mathrm{~d}$ & $\begin{array}{c}\mathrm{N}_{2} / \mathrm{CO}_{2}(95 / 5), \text { (no } \\
\text { gassing with periodic } \\
\text { gas replacement of } \\
\text { every } 3 \text { or } 4 \text { days) }\end{array}$ & $\begin{array}{l}\text { Sustained, high- } \\
\text { level production of } \\
\mathrm{H}_{2} \text { through } 21 \text { days }\end{array}$ & [49] \\
\hline
\end{tabular}




\section{Improvements Needed in the Energy Conversion Efficiency under Outdoor Conditions}

If photobiological $\mathrm{H}_{2}$ production is to be developed as a source of large-scale renewable energy, improvements are needed in both the light energy conversion efficiency and in the rates of $\mathrm{H}_{2}$ production. The maximum theoretical energy conversion for $\mathrm{N}_{2}$ ase-based photoautotrophic $\mathrm{H}_{2}$ production by cyanobacteria has yet to be precisely calculated. This is because $\mathrm{N}_{2}$ ase requires a considerable amount of ATP and the energy conversion efficiency of photophosphorylation has yet to be conclusively determined. There is a lack of information on the structure and function of the membrane ATP synthase $\left(\mathrm{H}^{+}\right.$-ATPase) that consumes the proton-motive force generated across membranes as the source of energy as predicted by the chemi-osmotic mechanism proposed by P. Mitchell $[57,58]$. Most likely, the $\mathrm{H}^{+}$/ATP ranges between $8 / 3$ and $14 / 3$ (for discussion, see $[21,59,60]$ ). By assuming an $\mathrm{H}^{+} / \mathrm{ATP}$ ratio of between 3 and 4, Sakurai and Masukawa [17] calculated the maximum energy conversion efficiency of between $16.3 \%$ and $13.9 \%$ for $550 \mathrm{~nm}$ light and between $7.3 \%$ and $6.3 \%$ for the total solar radiation, assuming cyanobacteria can use 45\% (400-700 nm light, PAR: photosynthetically active radiation) of total radiation.

Of special significance is a report of a record high $\mathrm{H}_{2}$ production activity on a chlorophyll basis by cyanobacteria. The $\mathrm{N}_{2}$ ase activity of the unicellular cyanobacterium Cyanothece sp. ATCC 51142 is regulated by circadian rhythms: photosynthesis in the light, and $\mathrm{N}_{2}$ ase reaction in the dark. When the cells were grown in the presence of glycerol for $12 \mathrm{~h}$ under the light to accumulate photosynthetic products (the first stage), they showed high photobiological $\mathrm{H}_{2}$ activity on a chlorophyll (Chl) basis of $465 \mu \mathrm{mol} \mathrm{mg} \mathrm{Chl}{ }^{-1} \cdot \mathrm{h}^{-1}$ when the illumination was continued for another $12 \mathrm{~h}$ (the second stage) [61]. This type of strain may be potentially useful if low cost organics are available, such as wastewater rich in useable organic compounds (e.g., from the food industry). However, as many of the heterocystous strains very poorly use organic compounds, this is currently not very promising for the improvement of $\mathrm{H}_{2}$ production by heterocystous strains.

\subsection{Comparing Measured Values for Light Energy Conversion Efficiency of Photobiological $\mathrm{H}_{2}$} Production by Cyanobacteria to Our Tentative Target Values of $1.2 \%$

Although values of $2.6 \%-3.7 \%$ of PAR in laboratory experiments were reported by several groups $[35,55,62]$, the values drop to $0.2 \%$ or less in outdoor experiments lasting for more than two days $[51,52,63,64]$ (daily maximum of $0.6 \%$, Miyamoto [51]) (Table 4). For our proposed scheme, we believe that $1.2 \%$ (of total radiation) or $2.7 \%$ of PAR for outdoor conditions are reasonable targets for improved efficiency. 
Table 4. Some records of light energy conversion efficiency and duration of the activity.

\begin{tabular}{|c|c|c|c|c|c|c|c|}
\hline Strains & Light Intensity & Efficiency (\%) & $\begin{array}{c}\text { Light } \\
\text { Energy }\end{array}$ & $\begin{array}{c}\text { Duration } \\
\text { of expt. }\end{array}$ & Gas & Remarks & Refs. \\
\hline $\begin{array}{c}\text { Mastigocladus } \\
\text { laminosus NZ-86-m }\end{array}$ & $\begin{array}{c}4.4 \times 10^{5} \\
\mathrm{erg} \cdot \mathrm{cm}^{-2} \cdot \mathrm{s}^{-1}\end{array}$ & $0.17 \%$ av. & $\begin{array}{l}\text { total } \\
\mathrm{rad} .\end{array}$ & $17-24 \mathrm{~d}$ & $\begin{array}{c}\mathrm{Ar} / \mathrm{N}_{2} / \mathrm{CO}_{2} \\
(98.7 / 1.0 / 0.3), \\
\text { gassing }\end{array}$ & $\begin{array}{l}1 \mathrm{~L} \text { culture: } \\
6.5 \mathrm{~L} \cdot \mathrm{gas} / \mathrm{h}\end{array}$ & {$[52]$} \\
\hline $\begin{array}{c}\text { Anabaena } \\
\text { cylindrica } 629\end{array}$ & $\begin{array}{l}\text { about } 50-330 \\
\mathrm{cal} \cdot \mathrm{cm}^{-2} \cdot \mathrm{d}^{-1}\end{array}$ & $\begin{array}{c}0.2 \% \text { av. } \\
0.6 \% \max .\end{array}$ & $\begin{array}{l}\text { total } \\
\text { rad. }\end{array}$ & $36 \mathrm{~d}$ & $\begin{array}{c}\mathrm{Ar} / \mathrm{N}_{2} / \mathrm{CO}_{2} \\
\text { (balance/ } \\
0.2-0.4 / 0.5 \text { ), } \\
\text { gassing }\end{array}$ & $\begin{array}{c}0.8 \text { L culture: } 5.0 \\
\mathrm{~L} \cdot \mathrm{gas} / \mathrm{h}\end{array}$ & {$[51]$} \\
\hline $\begin{array}{c}\text { Anabaena variabilis } \\
\text { PK84 }\end{array}$ & $\begin{array}{l}400 \mathrm{~W} \cdot \mathrm{m}^{-2} \\
\text { (sunny day) } \\
100 \mathrm{~W} \cdot \mathrm{m}^{-2} \\
\text { (cloudy day) }\end{array}$ & $\begin{array}{l}0.14 \% \text { (sunny } \\
\text { day) } 0.33 \% \\
\text { (cloudy day) }\end{array}$ & & $18 \mathrm{~d}$ & $\begin{array}{l}\text { air/ } \mathrm{CO}_{2} \\
(98 / 2), \\
\text { gassing }\end{array}$ & $\begin{array}{c}\text { chemostat-type } \\
\text { bioreactor, } \\
\text { possibly V-type } \\
\mathrm{N}_{2} \text { ase expressing } \\
\text { conditions }\end{array}$ & {$[65]$} \\
\hline $\begin{array}{l}\text { Anabaena variabilis } \\
\text { PK84 deficient of } \\
\text { the activities of both } \\
\text { Hup and Hox }\end{array}$ & $\max .850 \mathrm{~W} \cdot \mathrm{m}^{-2}$ & $0.029 \%-0.094 \%$ & $\begin{array}{l}\text { total } \\
\text { rad. }\end{array}$ & $40 \mathrm{~d}$ & $\begin{array}{l}\text { air } / \mathrm{CO}_{2} \\
(98 / 2), \\
\text { gassing }\end{array}$ & $\begin{array}{c}\text { chemostat-type } \\
\text { bioreactor, } \\
\text { possibly V-type } \\
\mathrm{N}_{2} \text { ase expressing } \\
\text { conditions, } \\
\text { June-July, London }\end{array}$ & {$[64]$} \\
\hline $\begin{array}{c}\text { Anabaena sp. PCC } \\
7120 \text { AMC } 414 \\
\text { deficient of Hup }\end{array}$ & $\max .600 \mathrm{~W} \cdot \mathrm{m}^{-2}$ & $0.042 \% \max$ & $\begin{array}{l}\text { total } \\
\mathrm{rad} .\end{array}$ & $9 \mathrm{~d}$ & $\begin{array}{l}\text { air } / \mathrm{CO}_{2} \\
(98 / 2), \\
\text { gassing }\end{array}$ & $\begin{array}{l}\text { chemostat-type } \\
\text { bioreactor, } \\
\text { August, London }\end{array}$ & {$[63]$} \\
\hline
\end{tabular}

\subsection{Some Potential Strategies to Achieve Higher Light Conversion Efficiencies}

Many aspects of the $\mathrm{H}_{2}$ production and the related technologies are under development currently, making it challenging to estimate production costs. Nevertheless, such estimates are informative for both policy-makers and investors in R\&D efforts. Sakurai et al. [44] presented a preliminary estimate of $26.4 \phi / \mathrm{kWh}$ (assuming the price of plastics at $\$ 2$ per $\mathrm{kg}$ ) as a means to identify the needed $\mathrm{R} \& \mathrm{D}$ efforts to achieve efficient photobiological $\mathrm{H}_{2}$ production by cyanobacteria. The conditions were: (1) mariculture-raised cyanobacteria produce $\mathrm{H}_{2}$ at an energy conversion efficiency of $1.2 \%$ $\left(18 \mathrm{kWh} \cdot \mathrm{m}^{-2} \cdot \mathrm{yr}^{-1}\right)$ in plastic bioreactors floating on the sea surface (solar radiation $1500 \mathrm{kWh} \cdot \mathrm{m}^{-2} \cdot \mathrm{yr}^{-1}$ ); (2) the crude $\mathrm{H}_{2}$ is purified on factory ships and transported to final destination ports in storage tanks by container ships; and (3) the energy recovery (from production to the final commodity of $\mathrm{H}_{2}$ ) is 0.5 . Although the tentatively estimated price above is more expensive than the currently levelized price of electricity, it is reasonably close to the prices in several countries with feed-in tariff schemes (see Section 1.3). The price of $\mathrm{H}_{2}$ can be further decreased with improvements in both light conversion efficiency and energy recovery, and by decreasing the processing costs with advancements in relevant technologies. Because photobiologically produced $\mathrm{H}_{2}$ contributes to the reduction of the greenhouse gas $\mathrm{CO}_{2}$ emissions, and because $\mathrm{H}_{2}$ fuel cells are expected to be more energy efficient than internal combustion engines, the R\&D of photobiological renewable energy sources should be pursued in more earnest. 
Amos [66] estimated the cost of $\mathrm{H}_{2}$ produced by Chlamydomonas to be $22.8 \phi / \mathrm{kWh}$ when $\mathrm{H}_{2}$ is compressed and stored in high-pressure tanks for storage and transportation, and $7.2 \notin / \mathrm{kWh}$ when direct connections to $\mathrm{H}_{2}$ pipelines are available. In certain locations, such as salt lakes, a pipeline could be used to transport gas products with reduction of the total cost of $\mathrm{H}_{2}$ photobiologically produced by cyanobacteria.

5.2.1. Selection of Strains with High N2ase Activity Outdoors Followed by Further Improvements via Genetic Engineering

Yoshino et al. [35] compared the photobiologically driven N2ase activity under laboratory conditions among 13 heterocystous strains maintained in academic centers, and selected Nostoc sp. PCC 7422. The uptake hydrogenase knocked out mutant ( $\Delta \mathrm{Hup}$ ) produced $\mathrm{H}_{2}$ at an energy conversion efficiency of $3.7 \%$ vs. PAR under laboratory conditions. Selection of strains with high $\mathrm{N}_{2}$ ase activity under outdoor conditions with high light intensities followed by further targeted improvements via genetic engineering seems to one of the most promising strategies for achieving higher light conversion efficiencies.

\subsubsection{Truncated Antenna Complexes}

Light-saturation of photobiological activity is one of main reasons light conversion efficiencies are decreased under outdoor conditions as compared with the laboratory conditions for cyanobacteria. Many cyanobacterial strains have large antenna complexes containing pigments such as phycocyanin, which enable them to survive even under conditions of low light intensity such as in a dense culture or in sediment. In order for photobiological $\mathrm{H}_{2}$ production schemes of the culture as a whole to operate at optimum efficiency, large antenna size is a problem because cells near the surface absorb the most part of incident light and are unable to use it efficiently because of light saturation, while other cells beneath them receive only the residual low light. It is hypothesized that truncation of antenna size would help to alleviate excess absorption of sunlight and the ensuing wasteful dissipation of excitation energy, and to improve solar-to-product energy conversion efficiency and photosynthetic productivity in high-density mass cultivations. As proof of this concept, there are reports of truncated antenna cyanobacterial mutants showing higher rates of photosynthetic activity in culture over the wild-type strains [67].

\subsubsection{Increase in Heterocyst Frequency}

Under conditions of nitrogen deprivation, heterocystous cyanobacterial cells differentiate heterocysts at intervals of 10-20 vegetative cells, depending upon the strains. While heterocyst frequency may be optimized to support growth of the strains while fixing $\mathrm{N}_{2}$ under their ordinary natural habitats, the frequency can also be modified to increase $\mathrm{H}_{2}$ production because the cells do not grow in the $\mathrm{H}_{2}$ production stage and thus the supply of organic compounds for growth can be dispensed. Many genes involved in heterocyst differentiation have been reported and the mutants of several of these genes (via disruption, overexpression, and duplication of genes and point mutation) result in higher frequencies of heterocysts $[25,26,68]$. However, many of the mutants form multiple contiguous heterocysts and their $\mathrm{N}_{2}$ ase activities measured by acetylene reduction do not exceed the wild-type activities. PatN is required for normal heterocyst patterning and has a role in the biased initiation of heterocyst differentiation. In Nostoc/Anabaena sp. PCC 7120, disruption of pat $N$ led to formation of multiple singular heterocysts. 
Although the pat $N$ mutant exhibited lower $\mathrm{N}_{2}$ ase activity and diazotrophic growth rate compared with the wild-type [69], it will be interesting to see the effects of modification of heterocyst frequency on photobiological $\mathrm{H}_{2}$ production by other strains or under different experimental conditions.

\subsubsection{Improvement of the Enzymatic Activity of $\mathrm{N}_{2}$ ase}

Other $\mathrm{H}_{2}$-producing enzymes, $\mathrm{FeFe}$ and $\mathrm{NiFe} \mathrm{H}_{2}$ ases, have high $\mathrm{H}_{2}$ production activity with a turnover rate of 6000-9000 and about $100 \mathrm{~s}^{-1}$, respectively, although the latter enzyme also has greater $\mathrm{H}_{2}$ uptake activity with a turnover rate of 450-600 $\mathrm{s}^{-1}$ [70]. In contrast, although $\mathrm{N}_{2}$ ase has an advantage in catalyzing unidirectional production of $\mathrm{H}_{2}$, it has a very low turnover rate of about $6.4 \mathrm{~s}^{-1}[71,72]$. The rate-limiting step in $\mathrm{N}_{2}$ ase catalysis is the dissociation of the dinitrogenase reductase Fe protein (Complex 2) from the dinitrogenase MoFe protein (Complex 1). The dissociation occurs after ATP-coupled electron transfer between the two proteins. In the $\mathrm{N}_{2}$ ase reaction, $\mathrm{H}_{2}$ is evolved initially when $\mathrm{N}_{2}$ binds to the enzyme. The slow protein dissociation is considered to contribute to maximizing $\mathrm{N}_{2}$ reduction by suppressing $\mathrm{H}_{2}$ evolution, futile to nitrogen fixation, at the midpoint of the whole reaction. It will be interesting to engineer $\mathrm{N}_{2}$ ase, either MoFe-protein or Fe-protein, or both, by site-directed mutagenesis, to increase the turnover rate of $\mathrm{H}_{2}$ production by the enzyme.

When maintaining the $\mathrm{N}_{2}$ ase-based reactions at high levels, cyanobacteria require high levels of amino acids to support the synthesis of the inefficient enzyme, and the increase in the specific catalytic activity will decrease the burden of protein synthesis.

\subsubsection{Metabolic Engineering}

As in other organisms, studies of genomes, transcriptomes, proteomes, and metabolomes are ongoing in cyanobacteria. The information from these studies will undoubtedly contribute to improving the overall activity of photobiological $\mathrm{H}_{2}$ production by cyanobacteria, as targeted improvements will be made [73]. For example, it will be interesting to pursue repression of the expression of glutamine synthetase in heterocysts. In normal cells, the enzyme is required for the massive export of fixed nitrogen from heterocyst to vegetative cells, and the gene expression level is greatly increased during the course of heterocyst differentiation [74]. $\mathrm{In}_{2}$ producing cyanobacteria, however, massive glutamine transport is not necessary because the cells almost cease growing, and the investment of amino acids for the synthesis of proteins such as glutamine synthetase seems to be a waste of amino acid reserves.

\section{Conclusions}

\section{Future Prospects for Large-Scale Photobiological $\mathrm{H}_{2}$ Production}

In order for photobiologically produced $\mathrm{H}_{2}$ to make meaningful contributions to the mitigation of global warming caused by greenhouse gases, notably $\mathrm{CO}_{2}$, economical production of $\mathrm{H}_{2}$ is essential. Although many of the technologies required for the practical application of large-scale photobiological $\mathrm{H}_{2}$ production are in the development stages and the cost estimates of the produced $\mathrm{H}_{2}$ are preliminary due to various unpredictable factors, Sakurai et al. [44] presented a very preliminary estimate of 26.4 cents $\cdot \mathrm{kWh}^{-1}$ of $\mathrm{H}_{2}$ produced on the sea surface using many presumptive assumptions, for example assuming the solar energy conversion efficiency of $1.2 \%$. Currently, the maximum energy conversion 
efficiency of cyanobacterial $\mathrm{H}_{2}$ production under outdoor conditions is about $0.2 \%$. There is an urgent need to demonstrate higher efficiencies to policy makers and developers in order to convince them of the potential benefits of photobiological $\mathrm{H}_{2}$ production by cyanobacteria. Increasing the solar energy conversion efficiency with improvements in technologies for purifying and transporting $\mathrm{H}_{2}$ will decrease the total cost. Public acceptance of renewable fuels very much depends upon the affordability of the price and will go a long way towards convincing consumers and government leaders to adopt technologies that will ultimately mitigate global climate change. Future cost estimates will be more accurate as the technologies in cyanobacterial $\mathrm{H}_{2}$ production and its related processes advance. We also expect that more refined cost estimates will allow for additional targeted improvements in the technologies, ultimately resulting in an overall cost reduction.

If we are able to produce $\mathrm{H}_{2}$ at $1.2 \%$ of total radiation $\left(18 \mathrm{kWh} \cdot \mathrm{m}^{-2} \cdot \mathrm{yr}^{-1}\right)$ on the sea surface and purified $\mathrm{H}_{2}$ is delivered to the end users with a final energy yield of 0.5 , the net energy obtained is calculated to be $9 \mathrm{kWh} \cdot \mathrm{m}^{-2} \cdot \mathrm{yr}^{-1}$ or $32.4 \times 10^{6} \mathrm{~J} \cdot \mathrm{m}^{-2} \cdot \mathrm{yr}^{-1}$ [44]. The current world fuel energy consumption is estimated to be $460 \times 10^{18} \mathrm{~J}_{\mathrm{yr}^{-1}}$ (Table 1, [3]). It follows that by using a surface of the sea equivalent to $1 \%$ of the global surface $\left(1.36 \times 10^{6} \mathrm{~km}^{2}\right.$, about 2.3 times the area of the island of Tasmania, or 3.1 times the area of the island of Great Britain), we will be able to replace $19 \%$ of the current world fossil fuel consumption.

In order to make a meaningful contribution to the mitigation of the hazards to the human population that are predicted to occur with global climate change, the promotion of $R \& D$ efforts for economical large-scale photobiological biofuel production and the advancements of biological and other needed technologies should be encouraged.

\section{Acknowledgments}

We thank Susan Carlson for critically reading the manuscript. This work was supported in part by grant-in aid for Scientific Research on Innovative Areas (No. 24107004) and Strategic Research Base Development Program for Private Universities from MEXT, Japan (to KI).

\section{Conflicts of Interest}

One of the authors (H.S.) is a stakeholder of Wakhy Laboratories.

\section{References}

1. Intergovernmental Panel on Climate Change (IPCC). Summary for policymakers. Available online: https://ipcc-wg2.gov/AR5/images/uploads/WG2AR5_SPM_FINAL.pdf (accessed on 15 Feburary 2015).

2. United Nations Intergovernmental Panel on Climate Change(UNIPCC). Fifth Assessment Report. Available online: http://www.ipcc.ch/report/ar5/ (accessed on 15 Feburary 2015).

3. International Energy Agency (IEA). Key World Energy Statistics. Available online: http://www.iea.org/publications/freepublications/publication/KeyWorld2014.pdf (accessed on 15 Feburary 2015).

4. International Energy Agency (IEA). World Energy Outlook 2014. Available online: 
http://www.iea.org/publications/freepublications/publication/WEO_2014_ES_English_WEB.pdf (accessed on 15 Feburary 2015).

5. Angermayr, S.A.; Hellingwerf, K.J.; Lindblad, P.; de Mattos, M.J.T. Energy biotechnology with cyanobacteria. Curr. Opin. Biotech. 2009, 20, 257-263.

6. Ghirardi, M.L.; Dubini, A.; Yu, J.; Maness, P.C. Photobiological hydrogen-producing systems. Chem. Soc. Rev. 2009, 38, 52-61.

7. Huesemann, M.H.; Hausmann, T.S.; Carter, B.M.; Gerschler, J.J.; Benemann, J.R. Hydrogen generation through indirect biophotolysis in batch cultures of the nonheterocystous nitrogen-fixing cyanobacterium Plectonema boryanum. Appl. Biochem. Biotechnol. 2010, 162, 208-220.

8. Hallenbeck, P. Hydrogen Production by Cyanobacteria. In Microbial Technologies in Advanced Biofuels Production; Hallenbeck, P.C., Ed.; Springer: New York, NY, USA, 2012; pp. 15-28.

9. Hallenbeck, P.C.; Abo-Hashesh, M.; Ghosh, D. Strategies for improving biological hydrogen production. Bioresour. Technol. 2012, 110, 1-9.

10. Stephens, G.L.; Li, J.; Wild, M.; Clayson, C.A.; Loeb, N.; Kato, S.; L'Ecuyer, T.; Stackhouse, P.W.; Lebsock, M.; Andrews, T. An update on Earth's energy balance in light of the latest global observations. Nat. Geosci. 2012, 5, 691-669.

11. Wikipedia. Feed-in tariffs in Germany. Available online: http://en.wikipedia.org/wiki/Feedin_tariffs_in_Germany (accessed on 15 February 2015).

12. Lang, M.; Lang, A. German Feed-in Tariffs 2014 (from 08). Available online: http://www.germanenergyblog.de/?page_id=16379 (accessed on 15 February 2015).

13. The Ministry of Economy, Trade and Industry (METI), Japan. Settlement of FY2014 Purchase Prices and FY2014 Surcharge Rates under the Feed-in Tariff Scheme for Renewable Energy. Available online: http://www.meti.go.jp/english/press/2014/0325_03.html (accessed on 15 February 2015).

14. US Energy Information Administration (EIA). Levelized Cost of New Generation Resources in the Annual Energy Outlook 2013. Available online: http://www.eia.gov/forecasts/aeo/er/ pdf/electricity_generation.pdf (accessed on 15 February 2015).

15. Toyota Motor Corporation. Powering the future-hydrogen fuel cell vehicles could change mobility forever. Available online: http://www.toyota-global.com/innovation/environmental_ technology/fuelcell_vehicle/ (accessed on 15 February 2015).

16. Response JP. Tokyo Gas sets price of hydrogen for FCVs at 1100 yen per kilo. Available online: http://en.responsejp.com/article/2015/01/08/241157.html/ (accessed on 15 February 2015).

17. Sakurai, H.; Masukawa, H. Promoting R\&D in photobiological hydrogen production utilizing mariculture-raised cyanobacteria. Mar. Biotechnol. 2007, 9, 128-145.

18. Tamagnini, P.; Leitão, E.; Oliveira, P.; Ferreira, D.; Pinto, F.; Harris, D.J.; Heidorn, T.; Lindblad, P. Cyanobacterial hydrogenases: Diversity, regulation and applications. FEMS Microbiol. Rev. 2007, 31, 692-720.

19. Tsygankov, A.A. Nitrogen-fixing cyanobacteria: A review. Appl. Biochem. Microbiol. 2007, 43, 250-259.

20. Bothe, H.; Schmitz, O.; Yates, M.G.; Newton, W.E. Nitrogen fixation and hydrogen metabolism in cyanobacteria. Microbiol. Mol. Biol. Rev. 2010, 74, 529-551.

21. Sakurai, H.; Masukawa, H.; Kitashima, M.; Inoue, K. Photobiological hydrogen production: 
Bioenergetics and challenges for its practical application. J. Photochem. Photobiol. C 2013, 17, 1-25.

22. Berman-Frank, I.; Lundgren, P.; Falkowski, P. Nitrogen fixation and photosynthetic oxygen evolution in cyanobacteria. Res. Microbiol. 2003, 154, 157-164.

23. Finzi-Hart, J.A.; Pett-Ridge, J.; Weber, P.K.; Popa, R.; Fallon, S.J.; Gunderson, T.; Hutcheon, I.D.; Nealson, K.H.; Capone, D.G. Fixation and fate of $\mathrm{C}$ and $\mathrm{N}$ in the cyanobacterium Trichodesmium using nanometer-scale secondary ion mass spectrometry. Proc. Natl. Acad. Sci. USA 2009, 106, 6345-6350.

24. Wolk, C.P.; Ernest, A.; Elhai, J. Heterocyst Metabolism and Development. In The Molecular Biology of Cyanobacteria; Bryant, D.A., Ed.; Kluwer Academic Publishers: Dordrecht, The Netherlands, 1994; pp. 769-823.

25. Kumar, K.; Mella-Herrera, R.A.; Golden, J.W. Cyanobacterial heterocysts. Csh. Perspect. Biol. 2010, 2, a000315.

26. Herrero, A.; Picossi, S.; Flores, E. Gene expression during heterocyst differentiation. Adv. Bot Res. 2013, 65, 281-329.

27. Tamagnini, P.; Axelsson, R.; Lindberg, P.; Oxelfelt, F.; Wunschiers, R.; Lindblad, P. Hydrogenases and hydrogen metabolism of cyanobacteria. Microbiol. Mol. Biol. Rev. 2002, 66, 1-20.

28. Schütz, K.; Happe, T.; Troshina, O.; Lindblad, P.; Leitão, E.; Oliveira, P.; Tamagnini, P. Cyanobacterial $\mathrm{H}_{2}$ production—a comparative analysis. Planta 2004, 218, 350-359.

29. Masukawa, H.; Zhang, X.H.; Yamazaki, E.; Iwata, S.; Nakamura, K.; Mochimaru, M.; Inoue, K.; Sakurai, H. Survey of the distribution of different types of nitrogenases and hydrogenases in heterocyst-forming cyanobactera. Mar. Biotechnol. 2009, 11, 397-409.

30. Kumazawa, S.; Mitsui, A. Comparative amperometric study of uptake hydrogenase and hydrogen photoproduction activities between heterocystous cyanobacterium Anabaena cylindrica B629 and nonheterocystous cyanobacterium Oscillatoria sp. strain Miami BG7. Appl. Environ. Microbiol. 1985, 50, 287-291.

31. Happe, T.; Schütz, K.; Böhme, H. Transcriptional and mutational analysis of the uptake hydrogenase of the filamentous cyanobacterium Anabaena variabilis ATCC 29413. J. Bacteriol. 2000, 182, 1624-1631.

32. Lindberg, P.; Schütz, K.; Happe, T.; Lindblad, P. A hydrogen-producing, hydrogenase-free mutant strain of Nostoc punctiforme ATCC 29133. Int. J. Hydrog. Energ. 2002, 27, 1291-1296.

33. Masukawa, H.; Mochimaru, M.; Sakurai, H. Disruption of the uptake hydrogenase gene, but not of the bidirectional hydrogenase gene, leads to enhanced photobiological hydrogen production by the nitrogen-fixing cyanobacterium Anabaena sp. PCC 7120. Appl. Microbiol. Biot. 2002, 58, 618-624.

34. Carrasco, C.D.; Holliday, S.D.; Hansel, A.; Lindblad, P.; Golden, J.W. Heterocyst-specific excision of the Anabaena sp strain PCC 7120 hupL element requires xisC. J. Bacteriol. 2005, 187, 6031-6038.

35. Yoshino, F.; Ikeda, H.; Masukawa, H.; Sakurai, H. High photobiological hydrogen production activity of a Nostoc sp. PCC 7422 uptake hydrogenase-deficient mutant with high nitrogenase activity. Mar. Biotechnol. 2007, 9, 101-112.

36. Khetkorn, W.; Lindblad, P.; Incharoensakdi, A. Inactivation of uptake hydrogenase leads to enhanced and sustained hydrogen production with high nitrogenase activity under high light 
exposure in the cyanobacterium Anabaena siamensis TISTR 8012. J. Biol. Eng. 2012, 6, 19.

37. Mikheeva, L.E.; Schmitz, O.; Shestakov, S.V.; Bothe, H. Mutants of the cyanobacterium Anabaena variabilis altered in hydrogenase activities. Z. Naturforsch C 1995, 50, 505-510.

38. Masukawa, H.; Inoue, K.; Sakurai, H.; Wolk, C.P.; Hausinger, R.P. Site-directed mutagenesis of the Anabaena sp. strain PCC 7120 nitrogenase active site to increase photobiological hydrogen production. Appl. Environ. Microbiol. 2010, 76, 6741-6750.

39. Zhang, X.H.; Sherman, D.M.; Sherman, L.A. The uptake hydrogenase in the unicellular diazotrophic cyanobacterium Cyanothece sp. strain PCC 7822 protects nitrogenase from oxygen toxicity. J. Bacteriol. 2014, 196, 840-849.

40. Benemann, J.R.; Weare, N.M. Hydrogen evolution by nitrogen-fixing Anabaena cylindrica cultures. Science 1974, 184, 174-175.

41. Benemann, J.R. Hydrogen and methane production by microalgae. In Handbook of Microalgal Culture: Biotechnology and Applied Phycology; Richmond, A., Ed.; Blackwell Publishing Ltd.: Oxford, UK, 2004; pp. 403-429.

42. Clarens, A.F.; Resurreccion, E.P.; White, M.A.; Colosi, L.M. Environmental life cycle comparison of algae to other bioenergy feedstocks. Environ. Sci Technol. 2010, 44, 1813-1819.

43. Campbell, P.K.; Beer, T.; Batten, D. Life cycle assessment of biodiesel production from microalgae in ponds. Bioresour Technol 2011, 102, 50-56.

44. Sakurai, H.; Masukawa, H.; Kitashima, M.; Inoue, K. A feasibility study of large-scale photobiological hydrogen production utilizing mariculture-raised cyanobacteria. Adv. Exp. Med. Biol. 2010, 675, 291-303.

45. Tredici, M.R. Mass production of microalgae: photobioreactors. In Handbook of Microalgal Culture: Biotechnology and Applied Phycology; Richmond, A., Ed.; Blackwell Publishing Ltd.: Oxford, UK, 2004; pp. 178-214.

46. Fernández-Sevilla, J.M.; Acién-Fernández, F.G.; Molina-Grima, E. Photobioreactors Design for Hydrogen Production. In Microbial BioEnergy: Hydrogen Production; Zannoni, D., Philippis, R.D., Eds.; Springer: Dordrecht, The Netherlands, 2014; pp. 291-320.

47. Kitashima, M.; Masukawa, H.; Sakurai, H.; Inoue, K. Flexible plastic bioreactors for photobiological hydrogen production by hydrogenase-deficient cyanobacteria. Biosci. Biotech. Bioch. 2012, 76, 831-833.

48. Mitsui, A.; Murray, R.; Entermann, B.; Miyazawa, K.; Polk, E. Utilization of marine blue-green algae and microalgae in warm water mariculture. In Biosaline Research-A Look to the Future Environmental Science Research; San Pietro, A., Ed.; Plenum Press: New York, NY, USA, 1981; pp. 215-225.

49. Masukawa, H.; Sakurai, H.; Hausinger, R.P.; Inoue, K. Sustained photobiological hydrogen production in the presence of $\mathrm{N}_{2}$ by nitrogenase mutants of the heterocyst-forming cyanobacterium Anabaena. Int. J. Hydrog. Energ 2014, 39, 19444-19451.

50. Geiszler, V.C.; Koros, W.J. Effects of Polyimide Pyrolysis Conditions on Carbon Molecular Sieve Membrane Properties. Ind. Eng. Chem. Res. 1996, 35, 2999-3003.

51. Miyamoto, K.; Hallenbeck, P.C.; Benemann, J.R. Solar-energy conversion by nitrogen-limited cultures of Anabaena cylindrica. J. Ferment Technol. 1979, 57, 287-293.

52. Miyamoto, K.; Hallenbeck, P.C.; Benemann, J.R. Hydrogen production by the thermophilic alga 
Mastigocladus laminosus: effects of nitrogen, temperature, and inhibition of photosynthesis. Appl. Environ. Microbiol. 1979, 38, 440-446.

53. Weissman, J.C.; Benemann, J.R. Hydrogen production by nitrogen-starved cultures of Anabaena cylindrica. Appl Environ. Microbiol. 1977, 33, 123-131.

54. Jeffries, T.W.; Timourian, H.; Ward, R.L. Hydrogen production by Anabaena cylindrica: Effects of varying ammonium and ferric ions, pH, and light. Appl. Environ. Microbiol. 1978, 35, 704-710.

55. Miyamoto, K.; Hallenbeck, P.C.; Benemann, J.R. Nitrogen fixation by thermophilic blue-green algae (cyanobacteria): Temperature characteristics and potential use in biophotolysis. Appl. Environ. Microbiol. 1979, 37, 454-458.

56. Berberoğlu, H.; Jay, J.; Pilon, L. Effect of nutrient media on photobiological hydrogen production by Anabaena variabilis ATCC 29413. Int. J. Hydrog. Energ. 2008, 33, 1172-1184.

57. Mitchell, P. Chemiosmotic coupling in oxidative and photosynthetic phosphorylation. Biol. Rev. Camb. Philos. Soc. 1966, 41, 445-502.

58. Mitchell, P. Possible molecular mechanisms of the protonmotive function of cytochrome systems. J. Theor. Biol. 1976, 62, 327-367.

59. Junge, W. Structure and function of photosystem I. In Primary Processes of Photosynthesis—Part 2: Principles and Apparatus; Renger, G., Ed.; RSC Publishing: Cambridge, UK, 2007; Volume 2, pp. $447-487$.

60. Petersen, J.; Förster, K.; Turina, P.; Gräber, P. Comparison of the $\mathrm{H}^{+} /$ATP ratios of the $\mathrm{H}^{+}$-ATP synthases from yeast and from chloroplast. Proc. Natl. Acad. Sci. USA 2012, 109, 11150-11155.

61. Bandyopadhyay, A.; Stöckel, J.; Min, H.T.; Sherman, L.A.; Pakrasi, H.B. High rates of photobiological $\mathrm{H}_{2}$ production by a cyanobacterium under aerobic conditions. Nat. Commun. 2010, 1, doi:10.1038/ncomms1139.

62. Kumazawa, S.; Mitsui, A. Efficient hydrogen photoproduction by synchronously grown cells of a marine cyanobacterium, Synechococcus sp. Miami BG 043511, under high cell-density conditions. Biotech. Bioeng. 1994, 44, 854-858.

63. Lindblad, P.; Christensson, K.; Lindberg, P.; Fedorov, A.; Pinto, F.; Tsygankov, A. Photoproduction of $\mathrm{H}_{2}$ by wildtype Anabaena PCC 7120 and a hydrogen uptake deficient mutant: from laboratory experiments to outdoor culture. Int. J. Hydrog. Energ. 2002, 27, 1271-1281.

64. Tsygankov, A.A.; Fedorov, A.S.; Kosourov, S.N.; Rao, K.K. Hydrogen production by cyanobacteria in an automated outdoor photobioreactor under aerobic conditions. Biotech. Bioeng. 2002, 80, 777-783.

65. Fedorov, A.S.; Tsygankov, A.A.; Rao, K.K.; Hall, D.O. Production of hydrogen by an Anabaena variabilis mutant in a photobioreactor under aerobic outdoor conditions. In Biohydrogen II; Miyake, J., Matsunaga, T., San Pietro, A., Eds.; Elsevier Science Ltd.: Oxford, UK, 2001; pp. 223-228.

66. Amos, W.A. Updated Cost Analysis of Photobiological Hydrogen Production from Chlamydomonas reinhardtii Green Algae; NREL/MP-560-35593; NREL: Golden, CO, USA, 2004.

67. Nakajima, Y.; Ueda, R. Improvement of photosynthesis in dense microalgal suspension by reduction of light harvesting pigments. J. Appl. Phycol. 1997, 9, 503-510.

68. Meeks, J.C.; Elhai, J. Regulation of cellular differentiation in filamentous cyanobacteria in free-living and plant-associated symbiotic growth states. Microbiol. Mol. Biol. Rev. 2002, 66, 94-121. 
69. Risser, D.D.; Wong, F.C.Y.; Meeks, J.C. Biased inheritance of the protein patn frees vegetative cells to initiate patterned heterocyst differentiation. Proc. Natl. Acad. Sci. USA 2012, 109, 15342-15347.

70. Hallenbeck, P.C.; Benemann, J.R. Biological hydrogen production; fundamentals and limiting processes. Int. J. Hydrog. Energ. 2002, 27, 1185-1193.

71. Thorneley, R.N.F.; Lowe, D.J. Kinetics and Mechanism of the Nitrogenase Enzyme System. In Molybdenum Enzymes; Spiro, T.G., Ed.; John Wiley: New York, NY, USA, 1985; pp. 221-284.

72. Burgess, B.K.; Lowe, D.J. Mechanism of molybdenum nitrogenase. Chem. Rev. 1996, 96, 2983-3011.

73. Lindblad, P.; Lindberg, P.; Oliveira, P.; Stensjö, K.; Heidorn, T. Design, engineering, and construction of photosynthetic microbial cell factories for renewable solar fuel production. Ambio 2012, 41, 163-168.

74. Ehira, S.; Ohmori, M.; Sato, N. Genome-wide expression analysis of the responses to nitrogen deprivation in the heterocyst-forming cyanobacterium Anabacna sp strain PCC 7120. DNA Res. 2003, 10, 97-113.

(C) 2015 by the authors; licensee MDPI, Basel, Switzerland. This article is an open access article distributed under the terms and conditions of the Creative Commons Attribution license (http://creativecommons.org/licenses/by/4.0/). 